\title{
The effect of type and level of protein, fibre and starch on nitrogen excretion patterns in rats
}

\author{
BY R. M. BEAMES* AND B. O. EGGUM \\ National Institute of Animal Science, Department of Animal Physiology and Chemistry, \\ Rolighedsvej 25, DK-1958 Copenhagen, Denmark
}

(Received 14 October 1980 - Accepted 10 February 1981)

1. Three series of nitrogen balance experiments were performed with growing rats to test the effect of type and level of protein, fibre and starch on $\mathrm{N}$ excretion patterns. The design involved eighteen treatments in a $3 \times 3 \times 2$ factorial experiment with five rats per dietary treatment. The eighteen treatments resulted from a combination of three protein treatments, thres: fibre treatments and two starch treatments. Protein treatments consisted of one level $(15 \mathrm{~g} \mathrm{~N} / \mathrm{kg} \mathrm{DM})$ of casein fortified with methionine, a protein of high digestibility, and two levels (15 and $20 \mathrm{~g} \mathrm{~N} / \mathrm{kg} \mathrm{DM}$ ) of autoclaved brown beans (Phaseolus vulgaris), a protein source of low digestibility. The fibre treatments were two levels of cellulose powder and one level of barley hulls. The two starch treatments were autoclaved potato starch and actoclaved and raw potato starch $(1: 1, w / w)$.

2. The inclusion of raw potato starch reduced true protein digestibility markedly when the protein source was casein, but the corresponding biological values were increased significantly with this treatment. This strongly indicated a movement of urea from the blood to the intestines. This assumption was also supported by significantly lower blood urea concentratiors in animals given raw starch. The influence of raw starch on true protein digestibility was, however, significantly less when cellulose and barley hulls were included. This is probably due to reduced transit time from fibre inclusion. The nature of the gut contents also supported this hypothesis.

3. The inclusion of raw potato starch when brown beans were the source of protein had much less effect on true protein digestibility and biclogical value than when casein was the protein source. This was probably due to the low digestibility of DM and protein in this food leaving sufficient energy and protein for maximum microbial growth. The inclusion of fibre also had little effect on $\mathrm{N}$ excretion patterns with the brown-bean diets.

4. An increase in the level of brown bean inclusion reduced true protein digestibility only on the diets containing raw starch whereas the biologic:al value was consistently reduced regardless of starch treatment. The lower biological values were associated with significantly higher blood urea concentrations. Increasing the level of brown bean inclusion also resulted in higher fresh weights of caecum, colon and contents.

5. The present work proves that, through dietary manipulation, it is possible to affect nitrogen excretion patterns in rats.

Because of the physical characteristics of carbohydrates, their inclusion in diets can modify gut function. For example, the water-holding capacity in the fibre fraction leads to a more rapid transit of food through the gut. Its absorptive properties may alter the availability of some nutrients (Eastwcod, 1973); it can also have an abrasive action in the intestinal wall (Hallsworth \& Coates, 1962).

Results obtained by different groups on the effect of fibre on protein utilization have been contradictory in that some have found a decrease in protein utilization with an increasing fibre level while others have been unable to detect any effect (see Eggum, 1973). For example, Eggum (1973) found no effect of level of fibre (cellulose powder inclusion at levels up to $300 \mathrm{~g} / \mathrm{kg}$ in the diet) on true protein digestibility (TD), biological value (BV), and net protein utilization (NPU) of casein in rats. Sauer et al. (1979) were also unable to detect any effect of increasing levels of either purified or natural fibre sources. However, in both these experiments, the proteins and starch were provided in highly digestible forms, thereby differing from practical diets where hind gut fermentation of undigested residues could influence the results. Contrary to these findings, Breite (1973) and Meier \& Poppe (1977)

* Present address: Department of Animal Science, The University of British Columbia, Vancouver, B.C. V6T 2A2 Canada. 
found a decrease in TD as well as amino acid availabilities upon inclusion of increasing levels of natural fibre sources.

Eggum \& Christensen (1974) studied the influence of various carbohydrates on protein utilization. Autoclaved potato starch was replaced by increasing amounts of glucose, sucrose, fructose and lactose. Glucose, fructose and sucrose appeared to have no specific influence on protein utilization when given in increasing amounts and when compared with autoclaved potato starch. Higher concentrations of lactose, however, caused diarrhoea. It was further shown that true digestibility of the protein components in a mixture was directly related to the true digestibility of each component, including proteins of low digestibility.

In order to study the effect of dietary protein level on protein utilization Eggum (1973) carried out experiments with rats given increasing amounts of protein from casein $+10 \mathrm{~g}$ DL-methionine $/ \mathrm{kg}$ and from soya-bean meal. The conclusion from these experiments was tha TD is independent of dietary protein level, whereas apparent protein digestibility and $\mathrm{BV}$ are dependent of dietary protein level.

However, there is no doubt that the presence of a population of micro-organisms in the alimentary tract of single-stomached animals and man can affect nitrogen metabolism and that this effect under certain conditions will be significant. Several experiments have shown that the intestinal flora can degrade amino acids, amides, urea, etc. (Michel, 1966) as well as carbohydrates (Mason, 1980). The metabolic activity of hind-gut micro-organisms is thus well documented. The type and extent of fermentation is strongly influenced by the efficiency with which food is digested and absorbed in the upper tract.

Fibre digestion is almost entirely confined to the large intestine (Farrell \& Johnson, 1972). Starch digestion, however, occurs mainly in the upper tract, but there are several situations which encourage its degradation in the large intestine. An important factor influencing starch digestion is the physical nature of the starch granules, raw tuber starches in particular being much less digestible in the small intestine than those of cereal (Baker et al. 1950; Mason \& Just, 1976). These workers observed that whereas maize-starch granules were well digested in the small intestine of pigs, granules of raw potato starch accumulated in the caecum where they were subjected to intensive attack by the microflora. Heat treatment of tuber starch greatly improves its digestibility (Delort-Laval et al. 1968; Whittemore et al. 1973) and reduces the quantity of starch fermented in the large intestine. Irrespective of the carbohydrate type, its degradation by micro-organisms leads to the production of acetic, propionic, butyric, lactic and other organic acids in addition to carbon dioxide, methane and hydrogen.

In addition to their degradative activity, the microflora of the large intestine assimilate nitrogenous materials into their cell components. This assimilation is principally based on ammonia, but peptides and amino acids can be utilized by some bacterial species (Payne, 1975). It is known, moreover, that in addition to its responses to the type and quantity of dietary $\mathbf{N}$, faecal $\mathbf{N}$ excretion by single-stomached animals is influenced by the amount and type of fibre, starch and sucrose in the diet (Mason, 1978; Rerat, 1978).

It has been shown that an increase in the level of starch in the caecum, whether as a result of an increase in the level of dietary starch resistant to pancreatic amylase (EC 3.2.1.1), or by an infusion into the caecum, decreases apparent $\mathrm{N}$ digestion (Mason et al. 1976; Zebrowska et al. 1980) and decreases $\mathrm{N}$ excretion in the urine.

Information on the form of the $\mathrm{N}$ absorbed from the large intestine is still incomplete. It appears that most of this $\mathbf{N}$ is absorbed as ammonia (Hoover \& Heitmann, 1975) though under most conditions amine production and absorption may be appreciable (Milne \& Asatoor, 1975). Undoubtedly, some of the ammonia arises from the degradation of urea, which is present in various body fluids in approximately equal concentrations (Chalmers et al. 1976) and diffuses freely into the gastrointestinal tract (Rerat et al. 1979). Studies with 
germ-free rats confirm that this compound diffuses into the alimentary canal in appreciable quantities (Combe \& Sacquet, 1966). Prior et al. (1974) have shown that this diffusion also occurs in the conventional horse. Thus, net absorption of $\mathbf{N}$ in the hind-gut represents the balance between the processes of degradation and assimilation reached by the microflora during the period of fermentation.

It is thus evident tha: hind-gut bacteria can influence the $\mathbf{N}$ excretion patterns of single-stomached animals. The practical significance of this change in the excretory routes of $\mathrm{N}$ has not been clearly defined in terms of the interaction between the level of fermentable carbohydrate, the form cof fibre and the protein passing beyond the terminal ileum. This experiment was designed to investigate some aspects of these interactions.

\section{EXPERIMENTAL}

\section{Diets}

The design involved a total of eighteen treatments in a $3 \times 3 \times 2$ factorial experiment with five rats per dietary treatment. The eighteen treatments resulted from a combination of three protein treatments, three fibre treatments and two starch treatments. Each diet was composed of a basal $\mathrm{N}$-free mixture containing the following amounts $/ \mathrm{kg}$ air-dry matter (89.2 g sucrose, $52.0 \mathrm{~g}$ cellulose, $52.0 \mathrm{~g}$ peanut oil and $806.8 \mathrm{~g}$ autoclaved potato starch) plus minerals and vitamins (Eggum, 1973), and various combinations of protein and carbohydrates. In proteir. treatment no. 1 , casein $+10 \mathrm{~g}$ DL-methionine $/ \mathrm{kg}$ provided 15.0 $\mathrm{g} \mathrm{N} / \mathrm{kg}$ dry matter (DM). In protein treatments nos. 2 and 3, protein was provided as autoclaved brown beans (Phaseolus vulgaris). The brown beans were mixed with water $(3: 1$, $\mathrm{w} / \mathrm{w}$ ) and autoclaved at $2 \mathrm{~atm}$. for $3 \mathrm{~h}$ and then dried for $3 \mathrm{~h}$. Brown beans $+5 \mathrm{~g}$ DL-methionine $/ \mathrm{kg}$ DM prcivided $15.0 \mathrm{~g} \mathrm{~N} / \mathrm{kg}$ DM in protein treatment no. 2 and $20.0 \mathrm{~g} \mathrm{~N} / \mathrm{kg}$ DM in protein treatment no. 3. The three fibre treatments were: no addition to the level of cellulose $(50 \mathrm{~g} / \mathrm{kg})$ in the basal diet, or addition of $100 \mathrm{~g}$ cellulose (treatment no. 2) or 100 $\mathrm{g}$ barley hulls (treatment 110.3 )/ $\mathrm{kg}$ DM. A starch treatment was also included by replacing, on a DM basis, half the autoclaved potato starch in the basal $\mathrm{N}$-free diet with raw potato starch. The treatments ari: shown in Table 1. The sources of nutrients were added at the expense of the $\mathbf{N}$-free portion of the basal diet.

\section{Animals and feeding}

The experimental procedure has been described by Eggum (1973). Groups of five Wistar male rats weighing apprciximately $68 \mathrm{~g}$ were used in the experiments with preliminary periods of $4 \mathrm{~d}$ and balancis periods of $5 \mathrm{~d}$. In protein treatments nos. 1 and 2 each animal received $150 \mathrm{mg} \mathrm{N}$ and $10 \mathrm{~g}$ DM daily throughout the preliminary and the balance periods while rats on protein treatment no. 3 received $200 \mathrm{mg} \mathrm{N}$ and $10 \mathrm{~g}$ DM daily.

$\mathrm{TD}, \mathrm{BV}$ and NPU were measured. In protein treatments nos. 1 and $3 \mathrm{DM}$ digestibility was also measured. Due to a misunderstanding, DM digestibility was not measured in protein treatment no. 2.

At the end of the experiments, all rats were killed. Whole blood was collected from the vena cava and analysed for urea. The combined caecum and colon, including contents (CCC), was excised and weighed.

\section{Chemical analyses}

The chemical composition of samples was determined according to standard methods (Association of Official Analytical Chemists, 1975), with the exception that acid-hydrolysis followed by diethyl ether extraction was used for the estimation of fat (Stoldt, 1952). Amino acid analyses were carried out according to Mason et al. (1980). Blood urea was measured by the method of Conway' \& O'Malley (1942). 
R. M. BEAMES AND B. O. EgGuM

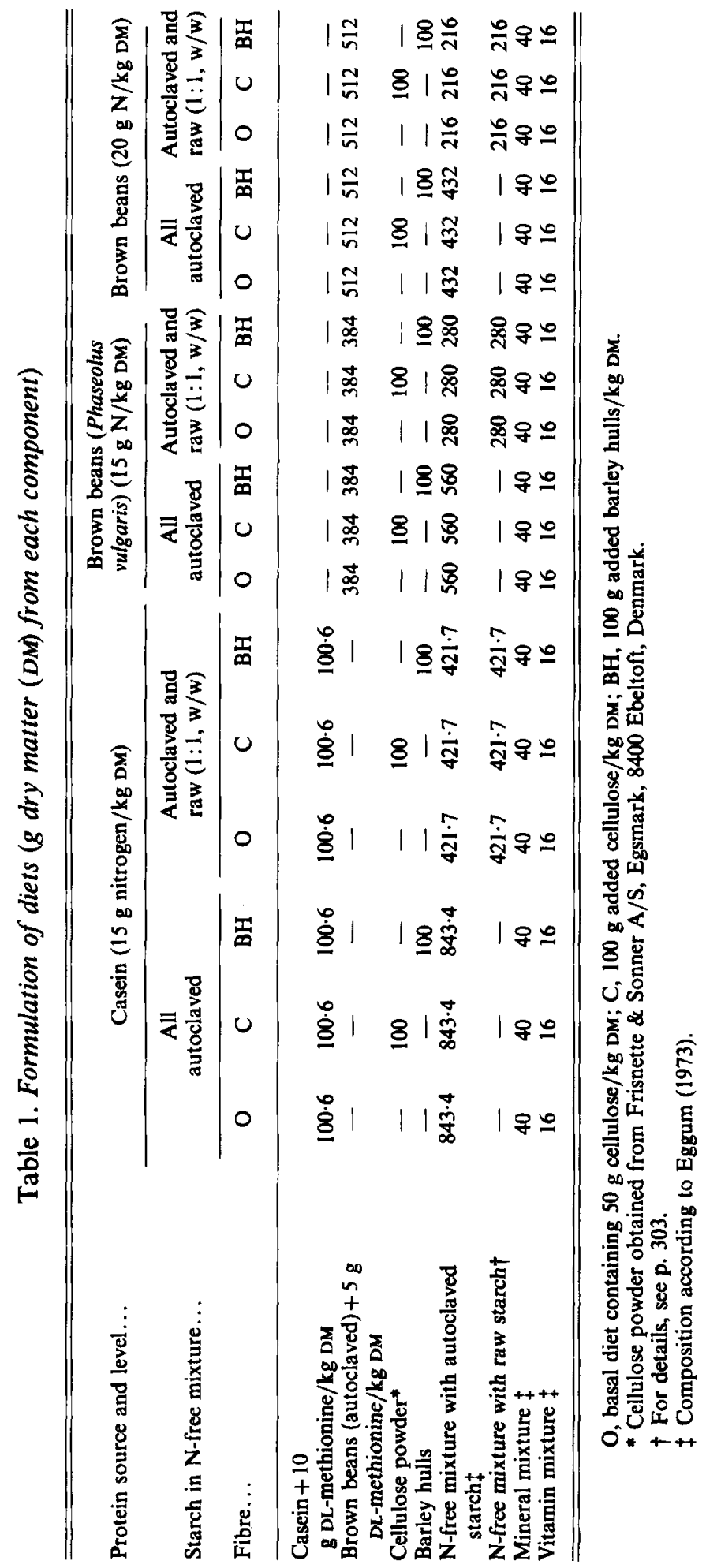


Table 2. Proximate analysis of casein, brown beans (Phaseolus vulgaris), cellulose powder and barley hulls and amino acid content of casein and brown beans

\begin{tabular}{|c|c|c|c|c|}
\hline & Casein & $\begin{array}{c}\text { Brown } \\
\text { beans }\end{array}$ & $\begin{array}{l}\text { Cellulose } \\
\text { powder }\end{array}$ & $\begin{array}{l}\text { Barley } \\
\text { hulls }\end{array}$ \\
\hline Dry matter $(\mathrm{DM})(\mathrm{g} / \mathrm{kg})$ & 884 & 863 & 920 & 921 \\
\hline \multicolumn{5}{|l|}{ Composition (g/kg DM) } \\
\hline Crude protein (nitrogen $\times 6.25$ ) & $931 \cdot 0$ & $225 \cdot 2$ & $2 \cdot 5$ & $31 \cdot 3$ \\
\hline Diethyl ether extract after acid-hydrolysis & 14.9 & $23 \cdot 4$ & 0 & $21 \cdot 0$ \\
\hline Crude Fibre & 0 & 34.6 & 727 & $375 \cdot 1$ \\
\hline Ash & $35 \cdot 2$ & $38 \cdot 3$ & 0 & $56 \cdot 1$ \\
\hline Nitrogen-free extract & $19 \cdot 0$ & $678 \cdot 5$ & 273 & $561 \cdot 5$ \\
\hline \multicolumn{5}{|l|}{ Amino acids $(\mathrm{g} / \mathrm{kg}$ protein $(\mathrm{N} \times 625))$} \\
\hline Alanine & $32 \cdot 1$ & $42 \cdot 9$ & & \\
\hline Arginine & $39 \cdot 7$ & $57 \cdot 5$ & & \\
\hline Aspartic acid & 75.9 & $126 \cdot 8$ & & \\
\hline Cystine & 5.8 & 10.9 & & \\
\hline Glutamic acid & $224 \cdot 2$ & 168.6 & & \\
\hline Glycine & $20 \cdot 3$ & $40 \cdot 2$ & & \\
\hline Histidine & $31 \cdot 6$ & $29 \cdot 2$ & & \\
\hline Isoleucine & $52 \cdot 3$ & $46 \cdot 8$ & & \\
\hline Leucine & $97 \cdot 0$ & 83.8 & & \\
\hline Lysine & $84 \cdot 1$ & $68 \cdot 2$ & & \\
\hline Methionine & 30.9 & $12 \cdot 1$ & & \\
\hline Phenylalanine & $52 \cdot 0$ & 58.8 & & \\
\hline Proline & $76 \cdot 2$ & $41 \cdot 1$ & & \\
\hline Serine & $57 \cdot 3$ & 61.7 & & \\
\hline Threonine & $43 \cdot 5$ & 44.9 & & \\
\hline Tryptophan & 16.8 & $12 \cdot 7$ & & \\
\hline Tryosine & $56 \cdot 2$ & $37 \cdot 3$ & & \\
\hline Valine & 69.6 & 51.7 & & \\
\hline
\end{tabular}

Statistical analyses

All results were subjected to analysis of variance as outlined in the University of British Columbia programme BMD: 10V (Bjerring et al. 1975). All differences between means were tested at $P<0.05$, using the Newman-Keul's multiple range test included in the previouslymentioned programme.

\section{RESULTS}

Chemical composition

The proximate analysis of cietary components and amino acid composition of casein and brown beans is given in Tatle 2. Casein consisted primarily of protein, while brown beans contained much less protein and more of the other nutrients, especially $\mathrm{N}$-free extract (678.5 $\mathrm{g} / \mathrm{kg} \mathrm{DM})$.

$T D$

The inclusion of raw starch reduced TD markedly from 0.989 to 0.927 when the protein source was casein, had no marked effect with the low level of brown beans, and decreased TD with the high level of brown beans, but only on the high-fibre diets (Table 3). Although the over-all effect of fibre was to produce a slight increase in TD with the addition of either cellulose or barley hulls, this effect varied, depending on the source of protein and starch. TD was little affected by fibre source with the raw starch diets at either level of brown beans, 
R. M. BEAMES AND B. O. EgGUM

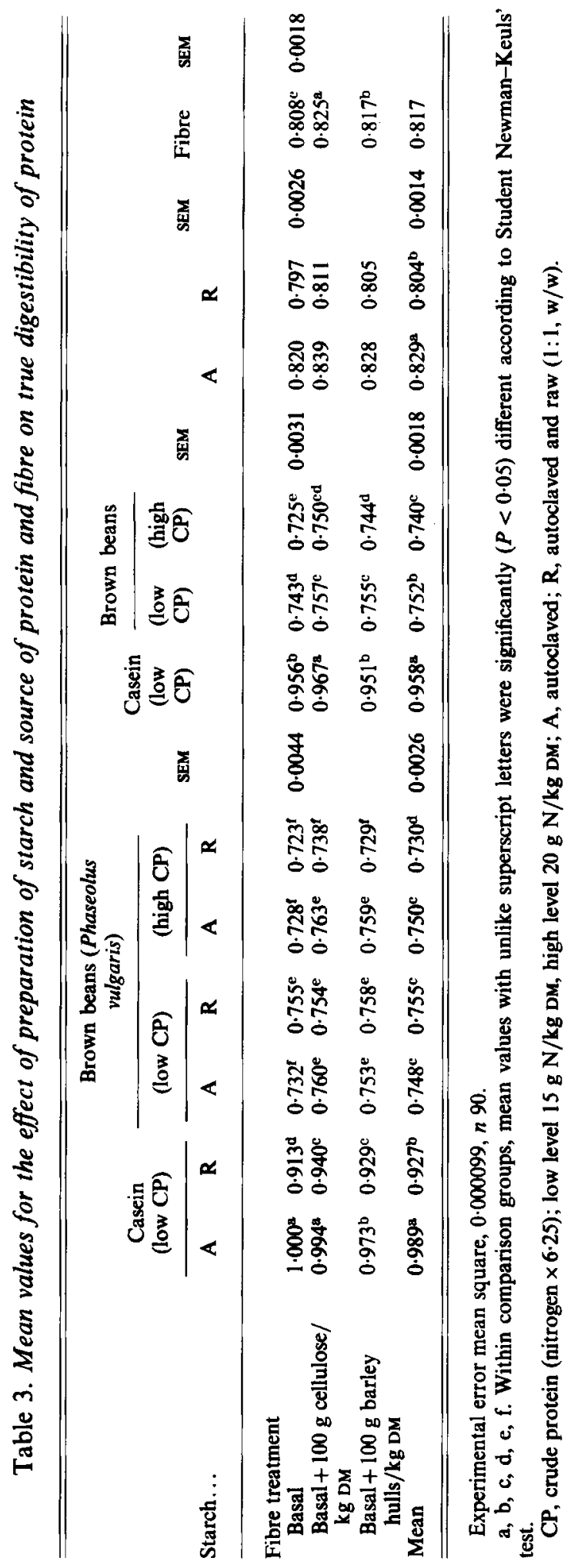


but TD improved with an increase in fibre level when casein was the protein source. On the autoclaved starch diets an increase in fibre level decreased TD when casein was the protein source, but increased TD on the two levels of brown beans.

$B V$

The inclusion of raw starch in the diet improved $\mathrm{BV}$ from 0.909 to 0.944 on diets in which the protein source was casein, but the effect of raw starch on the diets containing brown beans was either absent or small (Table 4). The casein diets and brown-bean diets containing the same $\mathrm{N}$ level (15 $\mathrm{g} \mathrm{N} / \mathrm{kg} \mathrm{DM}$ ), had similar BV when starch was autoclaved, but the BV was lower with the higher level of brown bean inclusion.

The responses of $\mathrm{BV}$ to fibre inclusion varied between protein treatments. BV was not markedly affected by fibre treatment when casein was the protein source, but was significantly reduced at toth levels of brown bean inclusion. At the lower level of brown bean inclusion ( $15 \mathrm{~g} \mathrm{~N} / \mathrm{kg} \mathrm{DM})$, both fibre sources decreased BV to approximately the same extent. At the higher level of brown bean inclusion $(20 \mathrm{~g} \mathrm{~N} / \mathrm{kg} \mathrm{DM})$ the decrease in $\mathrm{BV}$ on the barley-hull diets was significantly greater than on the cellulose diets.

\section{NPU}

As NPU is a derived value (TD $\times$ BV), this criterion is directly dependent on the values for digestibility and $\mathrm{Bv}$. Thus, the effect of autoclaving the starch, which differed markedly from one protein treatment to another as regards TD and BV, was much smaller with the NPU measurements. This resulted from TD and BV values being affected in different directions. Fibre treatment had no effect on NPU when starch was autoclaved, but with the raw starch diets, NPU was reduced in diets containing the barley hulls. This reduction occurred on both levels of brown bean inclusion.

\section{Blood urea concentration}

The greatest effect on blood urea was caused by the starch treatment, where the mean effect of the raw starch was to reduce concentration from $183 \mathrm{mg} / \mathrm{l}$ to $105 \mathrm{mg} / 1$. This reduction occurred on all protein treatments, although the mean reduction with the casein treatments $(97 \mathrm{mg} / \mathrm{l})$ was greater than that resulting from the brown-bean diets $(22$ and $53 \mathrm{mg} / \mathrm{l}$, respectively, for the low and high levels). Fibre treatments significantly affected blood urea concentration, with the effects being greater with the raw starch diets than with the autoclaved starch diets. On the raw starch diets, urea concentration was $70 \mathrm{mg} / \mathrm{l}$ when the fibre level was low ( $50 \mathrm{~g}$ cellulose $/ \mathrm{kg} \mathrm{DM}$ ), increasing to $131 \mathrm{mg} / 1$ when $100 \mathrm{~g}$ cellulose $/ \mathrm{kg}$ DM was added and to $115 \mathrm{mg} / \mathrm{l}$ when $100 \mathrm{~g}$ barley hulls $/ \mathrm{kg}$ DM was added.

\section{Dry matter digestibility}

DM digestibility was determined only on the casein-based and high-brown-bean diets. The DM digestibility of the ca:sein-based autoclaved-starch diet was 0.96 , with the digestibility being reduced by the partial replacement of autoclaved starch with uncooked starch and by the addition of fibre either as cellulose or barley hulls. The mean reduction in digestibility as a result of inclusion of raw starch was greater on the casein diets than on the brown-bean diets (from 0.91 to 0.75 is. 0.61 to 0.56 ). The DM digestibility on the barley-hull diets was consistently greater than that on the high cellulose diets.

\section{Weight of $C C C$}

The largest effect on the weight of CCC was caused by the inclusion of raw starch in the diet. This caused a mean weight increase on the casein diets from 3.5 to $7.3 \mathrm{~g}$, on the lowbrown-bean diets from 4.3 to $6.1 \mathrm{~g}$ and on the high-brown-bean diets from 5.5 to $7.0 \mathrm{~g}$. 
R. M. Beames AND B. O. EgGum

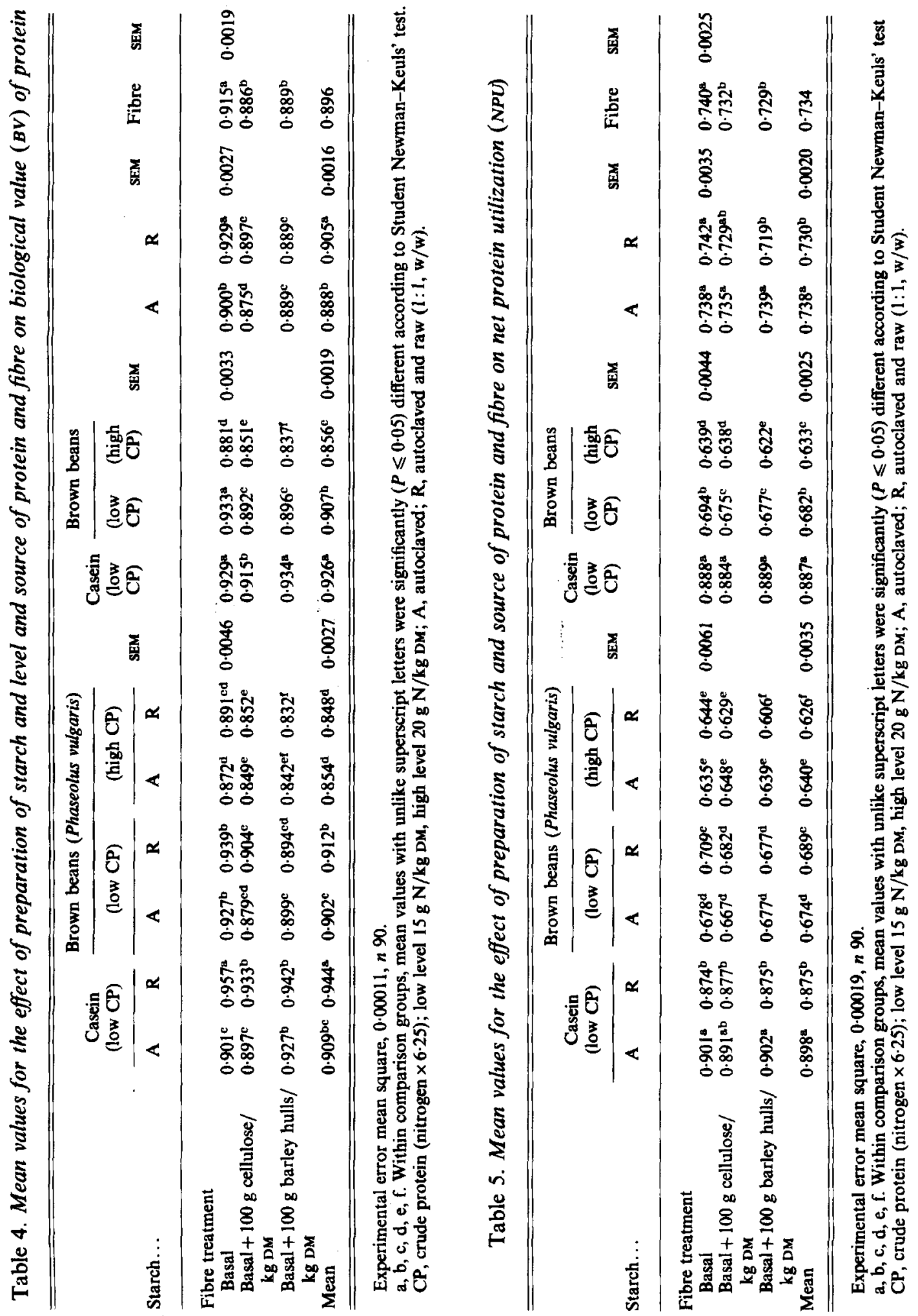




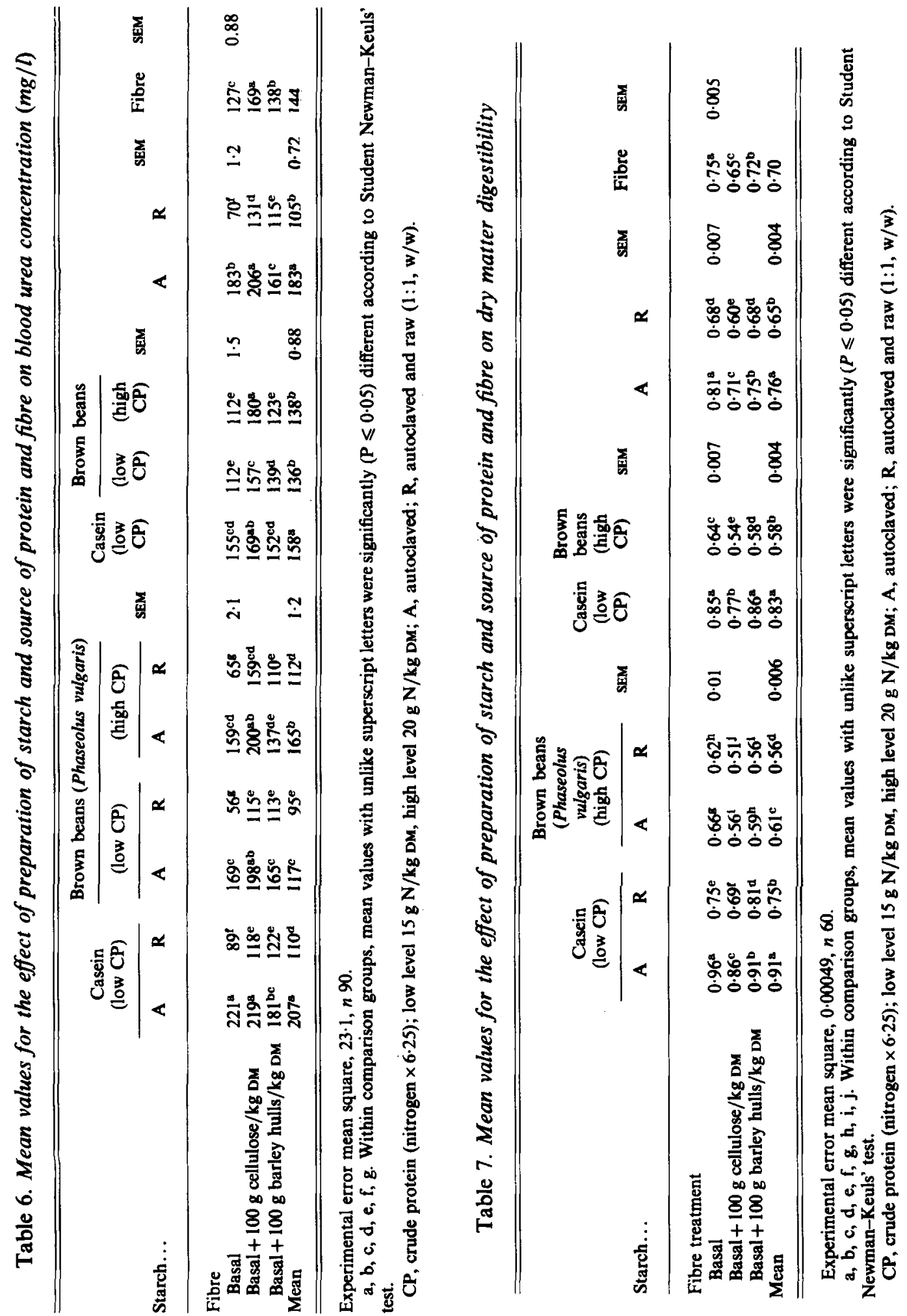




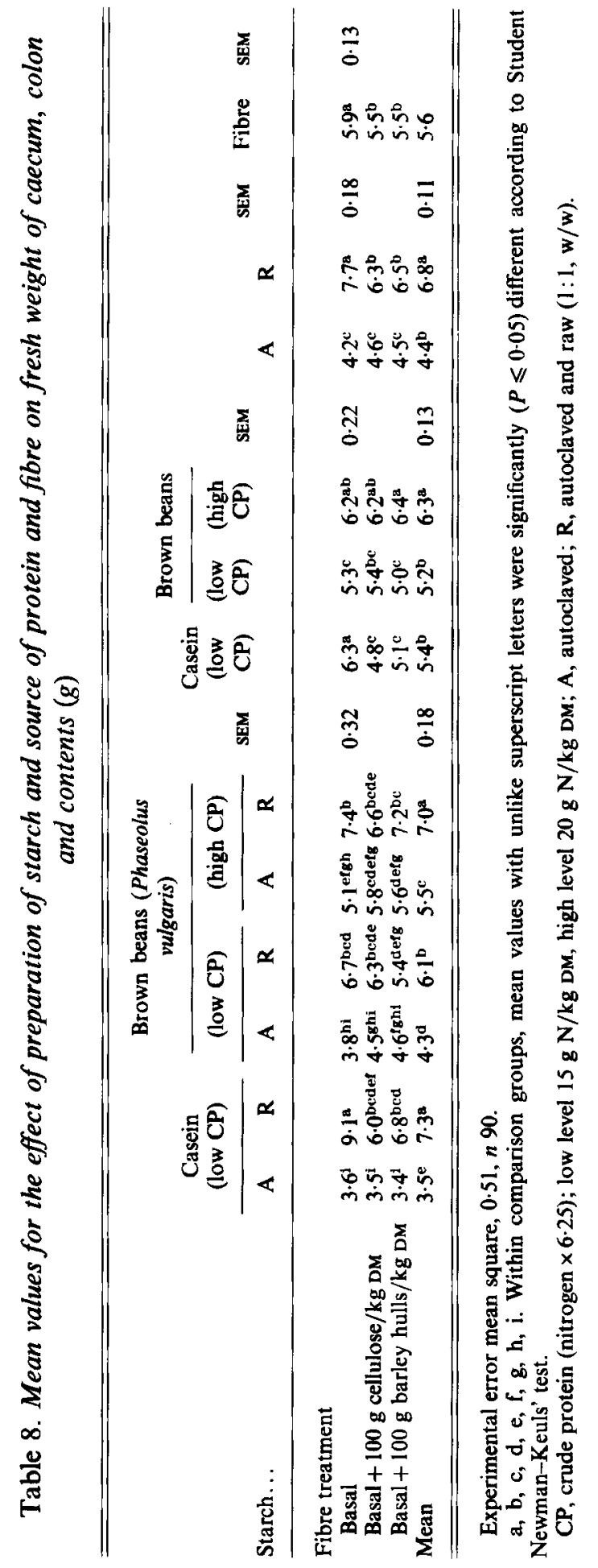


Fibre treatments had no miarked effect on the weight of CCC when the diets were based on autoclaved starch. When the diets were based on raw starch, however, the high crude fibre levels reduced the weight of $\mathrm{CCC}$.

\section{DISCUSSION}

The results confirm that the dietary level and type of protein, fibre and starch can have a significant influence on $\mathrm{N}$ excretion patterns of rats.

Casein-based diets. Raw potato starch had a marked negative influence on the digestibility of both protein and DM, thus supporting the results of Mason \& Just (1976). BV, however, was positively affected by raw potato starch in the casein diets, corresponding to the much lower blood urea concentrations on these diets. These results indicated a movement of urea from the blood (i.e., potentially from the urine) to the intestine (i.e., potentially to be excreted as faecal $N$ ) when the diet contained raw starch, thus supporting the results of Prior et al. (1974) and Zebrowska et al. (1980). A similar change in $\mathrm{N}$ excretion route from urine to faeces, but with a non-significant change in $\mathrm{N}$ balance was observed by Harmuth-Hoene \& Schwerdtfeger (1979) in rats receiving a casein-containing purified diet when it was supplemented with guar gum. Weight of $\mathrm{CCC}$ is correlated with the level of raw starch, which in turn is correlated with the extent of fermentation. In other words, sufficient energy was available to the microflora of the large intestine to allow the assimilation of nitrogenous materials into the cell components. As discussed by Payne (1975) this synthesis is principally based on ammonia which might originate from blood urea. This can thus explain the decrease in TD with a corresponding increase in BV, resulting in NPU being virtually unaffected. On the autoclaved-starch diets, an increase in fibre level had no effect on TD when the fibre source was cellulose, thereby agreeing with the results of Eggum (1973), but decreased TD when the fibre source was barley hulls. A similar decrease in TD with natural fibre sources was found by Breite (1973), Meier \& Poppe (1977) and Stephen \& Cummings (1979). With the raw starch diets, however, an increase in fibre level increased TD. This may have resulted from the high water-holding capacity of the fibre (Eastwood, 1973) causing a more rapid transit of food, with less fermentation and less absorption of urea in the hind-gut. This hypothesis is also supported by the much lower CCC in the high-fibre groups.

Low-brown-bean-based diets. Brown beans were included in this series of diets because of the low digestibility of this protein source compared to casein. It was thus assumed that brown-bean-based diets would contribute much more energy as well as protein for microbial fermentation in the hind-gut.

Rather surprisingly, the high fibre treatments improved TD in the diets containing autoclaved starch. It is believed that this was due to the reduced transit time of the high-fibre diets, leaving the microbe; less time to assimilate nitrogenous materials into their cell components. However, the decrease in BV indicate either less urea movement into the hind-gut or greater microbial degradative activities resulting in increased ammonia absorption from the hind-gut. This was especially the situation on the cellulose treatment while the effect of barley hulls was less pronounced. This is also indicated by the much higher blood urea concentration in the cellulose-treated group.

Raw starch had much less effect on the brown-bean-based diets than on the casein-based diets. This was probably due to the low digestibility of brown beans in general, leaving the microflora with sufficient energy irrespective of the extent of replacement of autoclaved starch with raw starch. The very low blood urea values and the high $\mathrm{BV}$ on the raw-starch-based diets indicated a very low ammonia absorption from the gut or a high urea movement into the git or both. In other words, there must have been an increase in the use of ammonia in the gut for the microbial protein synthesis.

High-brown-bean-baseddiets. The high-brown-bean-based diets wereincluded toinvestigate 
whether microbial growth was limited by the $N$ content of diets containing only $1.5 \mathrm{~g} \mathrm{~N} / \mathrm{kg}$ DM. A comparison of the corresponding diets containing the lower level of beans showed TD values to be very little affectd by the higher dietary protein concentration. This is in agreement with the conclusions of Eggum (1973), where his own results and earlier findings indicated TD to be independent of dietary protein concentration. The lower BV on these diets were also in agreement with earlier work (see Eggum, 1973). As expected (Eggum \& Christensen, 1974) the blood urea values increased when dietary protein levels were raised. The higher CCC on these diets than on the low-brown-bean-based diets might have been due to the high water-holding capacity of brown beans.

The present work has demonstrated that it is possible through dietary manipulation, to affect $\mathrm{N}$ excretion patterns in rats. However, it still remains to be determined whether this effect may be significant under more practical conditions. The results of Tao et al. (1971), Gruhn (1976) and Ostrowski (1975) have shown that lysine supplementation of lysinedeficient diets can improve protein digestibility. An interpretation of these findings could be that the reduced blood urea caused by the lysine supplementation would result in a lower urea diffusion into the hind-gut. This would result in a higher protein digestibility value.

Further work is in progress on the effect of protein quality and hind-gut microbial activity on these relationships.

The authors thank Miss I. Jacobsen and Mrs A. Tommerup for technical assistance, and Mrs M. Striker for helping with statistical analyses.

\section{REFEREN CES}

Association of Official Analytical Chemists (1975). Official Methods of Analysis, 1 lth ed. Washington, DC: Association of Official Analytical Chemists.

Baker, F., Nasr, H., Morrice, F. \& Bruce, J. (1950). J. Path. Bact. 62, 717.

Bjerring, J. H., Greig, M. \& Halm, J. (1975). U.B.C. BMD 10V. Vancouver, British Columbia: Computing Centre of University of British Columbia, Vancouver.

Breite, S. (1973). Modelluntersuchungen zum Einfluss exogener Faktoren auf die Aminosäurenresorbierbarkeit. Diss. (Promotion A), University of Rostock, Rostock.

Chalmers, M. I., Grant, I. \& White, F. (1976). Publ. Eur. Ass. Anim. Prod. no. 16, p. 159.

Combe, E. \& Sacquet, E. (1966). C.R. Acad. Sci. 262, 685.

Conway, E. J. \& O'Malley, E. (1942). Biochem. J. 36, 655.

Delort-Laval, J., Charlet-Lery, G., Zelter, S. Z., Mercier, C. \& Guilbot, A. (1968). Proc. 2nd Wld Conf. Anim. Prod., Maryland, p. 336.

Eastwood, M. A. (1973). Proc. Nutr. Soc. 32, 137.

Eggum, B. O. (1973). Natl Inst. Anim. Sci. Copenhagen. beretn 406.

Eggum, B. O. \& Christensen, K. D. (1974). Br. J. Nutr. 31, 213.

Farrell, D. J. \& Johnson, K. A. (1972). Anim. Prod. 14, 209.

Gruhn, K. (1976). Arch. Tierernähr. 24, 85.

Hallsworth, E. G. \& Coates, J. T. (1962). J. agric. Sci., Camb. 58, 153.

Harmuth-Hoene, A. E. \& Schwerdtfeger, E. (1979). Nutr. Metab. $23,399$.

Hoover, W. H. \& Heitmann, R. N. (1975). J. Nutr. 105, 245.

Mason, V. C. (1978). 3rd Wld Cong. Anim. Feeding, Madrid, p. 197.

Mason, V. C. (1980). In Current Concept of Digestion and Absorption in Pigs, [A. G. Low and I. G. Patridge, editors]. Reading: NIRD.

Mason, V. C., Bech-Andersen, S. \& Rudemo, M. (1980). Z. Tierephysiol. Tierernähr. Futtermittelk. 43, 146.

Mason, V. C. \& Just, A. (1976). Z. Tierphysiol. Tierernähr. Futtermittelk. 36, 301.

Mason, V. C., Just, A. \& Bech-Andersen, S. (1976). Z. Tierphysiol. Tierernähr. Futtermittelk. 36, 311.

Meier, H. \& Poppe, S. (1977). Zum Einfluss der Rohfaser auf die wahre Verdaulichkeit der Aminosäuren. Vth int. Symp. Amino Acids, p. C5. Budapest.

Michel, M. C. (1966). Annls Biol. anim. Biochim. Biophys. 6, 33.

Milne, M. D. \& Asatoor, A. M. (1975). In Peptide transport in Protein Nutrition, p. 167 [D. M. Mathews, editor]. Amsterdam: Elsevier.

Ostrowski, H. T. (1975). N.Z.Jl agric. Res. 18, 13.

Payne, J. W. (1975). In Peptide Transport in Protein Nutrition, p. 283 [D. M. Mathews, editor]. Amsterdam: Elsevier. 
Prior, R. L., Hintz, H. F., Lowe, J. E. \& Visek, W. J. (1974). J. Anim. Sci. 38, 565.

Rerat, A. (1978). J. Anim. Sci. 45, 1808.

Rerat, A., Lisoprawski, C., Vaisiade, P. \& Vaugelade, P. (1979). Bull. Acad. vet. Fr. 52, 333.

Sauer, W. C., Eggum, B. O. \& Jiacobsen, I. (1979). Arch. Tierernähr. 29, 533.

Stephen, A. M. \& Cummings, J. H. (1979). Proc. Nutr. Soc. 38, 141 A.

Stoldt, W. (1952). Fette Seifen, Anstrichm. 54, 206.

Tao, R., Belzile, R. J. \& Brisson, G. J. (1971). Can. J. Anim. Sci. 51, 705.

Whittemore, C. T., Taylor, A. C. \& Elsley, E. W. H. (1973). J. Sci. Fd Agric. 24, 539.

Zebrowska, T., Zebrowska, H. dz Buraczewska, L. (1980). 3rd Eur. Ass. Anim. Prod. Symp. Protein Metabolism and Nutrition, Braunschweig. 